\title{
高令者開腹手術前後の肺機能
}

\begin{tabular}{rrrrrr} 
& \multicolumn{5}{c}{ 鳥取大学第 1 外科 } \\
岩井 & 宣健 & 古賀 & 成昌 & 西村 & 興亜 \\
水本 & 清 & 岸 & 清志 & 日野原 & 徹 \\
竹内 & 勤 & & & &
\end{tabular}

\section{PULMONALY FUNCTIONS, BEFORE AND AFTER ABDOMINAL SURGERY OF AGED PATIENTS}

\section{Noritake IWAI, Sigemasa KOGA, Okitsugu NISHIMURA, Kiyoshi MIZUMOTO, Kiyoshi KISHI, Toru HINOHARA and Tsutomu TAKEUCHI}

First Department of Surgery, School of Medicine, Tottori University

70歳以上の高龄者の開腹手術前後に各種肺機能検查を施行し，術後肺合併症との相関を検討した．高龄 者の術後肺合併症の発生頻度は48％と高率であった．高龄者では，術前より多彩な肺の病変を有し，とく 飞慢性閉塞性肺疾患を併存する例では，術後肺合併症発生率が高く，かかる症例に対しては Flow-volume 曲線は有用な検査法である，術後では，早期の換気能障害は顕著であり，poor risk 例および肺合併 症合阙例では術前値への回復が非常に遅延した。術後の hypoxemia は無気肺に起因する shunt が主要 因と思われる。

索引用語：高令者開腹術後肺合併症, spirogram, 僈性閉塞性肺疾患, Flow-volume 曲線, 術後 hypoxemia

\section{緒喜}

高齢者の開腹術後合併症のうち，肺合併症は今もって 発生頻度が高くこれが致命的となる場合もまれではな い，肺合併症予防のためには，術前に spirogram を含 む各種肺機能検查成績を詳細に分析し，対処することが 必要であるが，高齢者は術前より多彩な肺の病態を有す るため，術後も様々な経過をとり，術前の検查成績とか ならずしも一致しないことは，臨床上しばしば経験され るところである。

そこで，70歳以上の高龄者開腹例に怙ける手術前後の 肺機能の動態から，高齢者に括ける術後肺合併症ならび に呼吸管理上の問題点について検討を加兄，若干の知見 を得たので，その成績に若干の考察を加えて報告する。

\section{対象および方法}

昭和52年の 1 年間において, 手術前後の各種肺機能検 查を施行し得た 70 歳以上の高齢者開腹例 25 例と 70 歳未満 の開腹例20例の計45例を研究対象とした。
表 1 症例

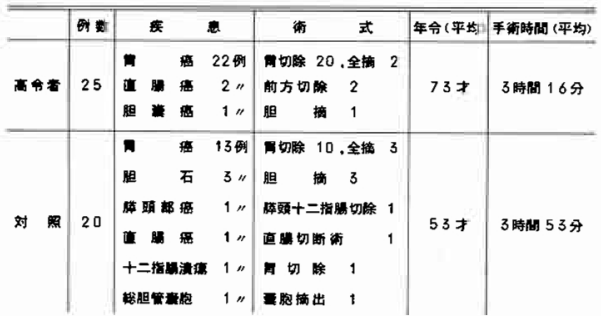

疾患別内訳ならびに手術々式は表 1 のごとくで，高龄 者群は胃癌22例, 直腸癌 2 例, 胆震癌 1 例で, 対照群は 胃癌 13 例, 胆石症 3 例, 膵頭部癌 1 例, 直腸癌 1 例, 十 二指腸潰瘍 1 例，総胆管瞔胞 1 例であった.

年龄分布は，10藏代 1 人，20代 1 人，40代 5 人，50代 5 人， 60 代 8 人， 70 代 22 人， 80 代 3 人であった. 平均手 術時間は高龄者群 3 時間16分，対照群 3 時間53分で, 高 秢者群の方が手術侵襲の少ない例が多かった。これら全 
症例は気管内挿管のもとに手術が行われた。

これらの症例に対し，日本光電社製オートスパイロメ ーター, $3 \mathrm{~Hz}$ 呼吸抵抗計, X-Y レコーダーを使用し, 術前呼吸機能を測定し，同時に安静時背臥位にて呼吸 数, 1 回換気量, 分時換気量, 肺活量を Wright respirometer にて測定した. また， Radiometer にて動脈血が ス分析を施行した。術後には第 4 病日まで毎日，呼吸 数, 肺活量, 呼吸抗抵, 1 回換気量, 分時換気量を測定 し，同時に動脈血ガス分析を施行した．さらに，換気能 に対する疼痛の影響を見るため，第 1 病日にペンタゾシ ソ15mg を笳注し, 注射前後に和ける肺活量の変動を見 た。

肺合併症の確認としては, 第 3 病日に胸部レ線撮影を 施行し, その他状況に応しその都度撮影し, 自, 他覚所 見を含め総合的に判断した。

\section{1. 術後肺合併症}

\section{成螋}

肺合併症としてどの範囲までを含めるかは問題のある ところである. 術後の胸水貯留は胃癌症例においては, リンパ節廓清, 摘脾, 横隔膜への機㑘的刺激などが加わ り，かなりの頻度に見られ，高龄者例にかならずしも多 いとは言えないが，手術を契機に発生したという意味で 合併症に含めた。

無気肺，肺炎，胸水貯留等の合併症は高龄者では12例 (48\%)，対照群では 3 例 (15\%) に見られ，高龄者での 合併率は高かった（表 2).

表 2 肺合併症内訳

\begin{tabular}{|c|c|c|c|c|}
\hline & 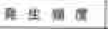 & $\kappa_{i}$ & & 8 \\
\hline क \& 8 & $\frac{12}{25}$ tant & 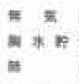 & $\begin{array}{l}\text { as } \\
\text { 部 } \\
\text { क }\end{array}$ & $\begin{array}{l}d= \\
4= \\
2=\end{array}$ \\
\hline \&s & $\frac{3}{20}(15.51)$ & 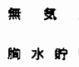 & & $\begin{array}{l}29 \\
1=\end{array}$ \\
\hline
\end{tabular}

\section{2. 術前肺機能と術後肺合併症}

肺機能検査の各種パラメーターのうち, 比肺活量, 1 秒率および Flow-volume 曲線（以下 $\dot{V}-\mathrm{V}$ 曲線と略す） の諸值と, 術後の肺合併症発生との関係を見た。

比肺活量（図 1 ）：対照群および 高柃者群ともに, 肺 合併症陽性群と陰珄群との間には，比肺活量では差異は 見られなかった。

1 秒率（図 2)：対照群では, 全例正常域にあり, 合 併症陽性群と陰性群との間にも，1秒率では差を認めな
区1 \% VC と肺合併症
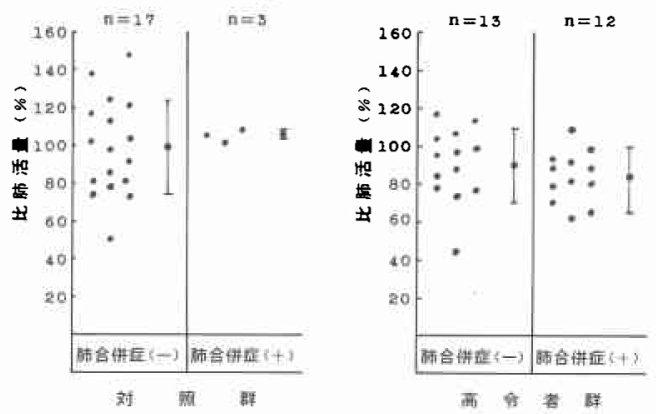

図2 1 秒率と肺合併症
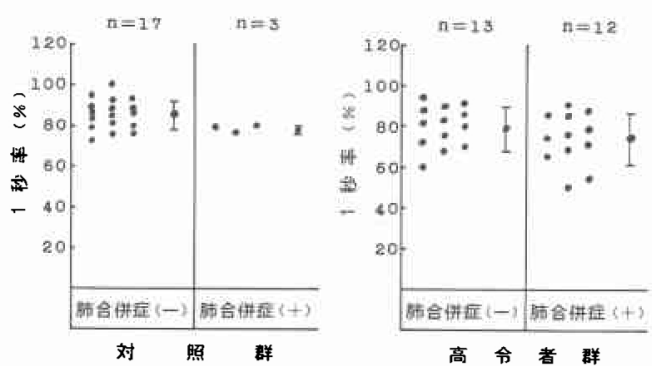

かった，高龊者群では，一般に対照群に比し，閉塞性換 気障害例が多い傾向にあったが，術後の肺合併症発生に 関しては，合併症陽性群と陰性群との間には差を認めな かった。

$\dot{V}-\mathrm{V}$ 曲線の 解析では, 肺活量 (FVC) を 4 等分した $75 \%, 50 \% ， 25 \%$ 肺活量点でのそれぞれの呼気速度 $\dot{\mathrm{V}}_{75}$, $\dot{\mathrm{V}}_{50}, \dot{\mathrm{V}}_{25}$ の各值沶よび最大流量 (PF) について検討し た. 表 3 に示すごとく，いずれのパラメーターに和いて も，高齢者群は対照群に比し，また，肺合併症陽性群は 除性群に比し低値を示したが，その值には非常なバラッ キがあり, $\mathrm{PF}, \dot{\mathrm{V}}_{75}, \dot{\mathrm{V}}_{50}, \dot{\mathrm{V}}_{25}$ などの単独の值からは, 一定の傾向は見出せなかった．な扣，この表の合併症陽

表 3 Flow-volume 曲線

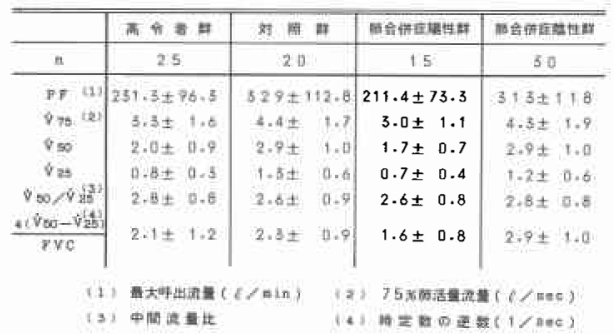


図 $3 \dot{\mathrm{V}}-\mathrm{V}$ 曲線と肺合併症
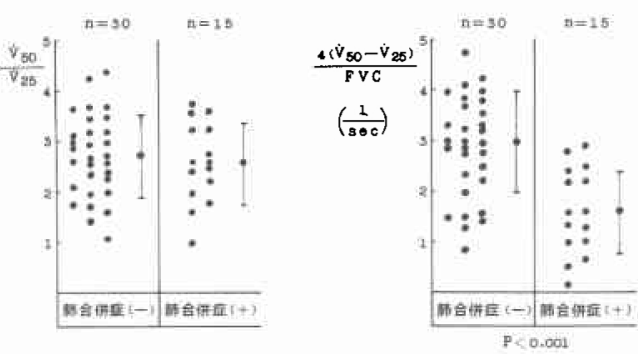

性群，陰性群は，いずれも高龄者群と対照群を含んた症 例である。

つぎに，図 3 のごとく， $\dot{\mathrm{V}}_{50} / \dot{\mathrm{V}}_{25}$ (中間流量比)でみる と, 高踰者群および対照群におけ㧊合併症陽性群と陰 性群との間には差は見られなかったが，これに肺活量の 値を考虑した $4\left(\dot{\mathrm{V}}_{50}-\dot{\mathrm{V}}_{25}\right) / \mathrm{VC}$ 值，すなわち，25\% VC 点と $50 \% \mathrm{VC}$ 点との間の曲線の勾配で比較すると, 陽 性群は $\mathrm{p}<0.001$ の有意差でもって低值を示した。すな わち, 低肺気量域での呼出障害例に, 術後肺合併症が多 く見られ，術前に何らかの末梢気道の閉塞を有する例に 合併症が多いといえる。

高龄者群のみについて検討しても（表 4),同様の傾向 で，高龄者肺合併症陽性群では， $4\left(\dot{\mathrm{V}}_{50}-\dot{\mathrm{V}}_{25}\right) / \mathrm{VC}$ が陰 性群に比し $\mathrm{p}<0.05$ の有意差で低値を示した。

表 4 高令者 Flow-volume 曲線

\begin{tabular}{|c|c|c|}
\hline & 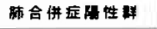 & 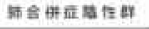 \\
\hline $\mathrm{m}$ & 12 & 13 \\
\hline PF & $196-5 \pm 74$ & $270 \pm 105$ \\
\hline$\dot{\vee} 75$ & $2.9 \pm 1.1$ & $3.7 \pm 1.9$ \\
\hline$\dot{\mathrm{v}} 50$ & $1.5 \pm 0.6$ & $2.6 \pm 1.0$ \\
\hline$\dot{v}_{25}$ & $0.7 \pm 0.4$ & $0.9 \neq 0.5$ \\
\hline$v_{50} / \dot{v}_{25}$ & $2 . t \pm 0 . a$ & $3.0 \pm 0.7$ \\
\hline$\frac{4\left(\dot{V}_{50}-\dot{V}_{25}\right)}{F V C}$ & $1.6 \pm 0.98$ & $2.7 \pm 1.2^{2 \%}$ \\
\hline
\end{tabular}

\section{3. 術後肺機能の変動 (図 4)}

術後の呼吸数: 第 1,2 病日が最も多く, 以後漸减乙 た. 対照群と高龄者群との対比では，対照群は第 1 病日 にピークを示し，以後漸減し，第 4 病日にはほぼ術前値 に復したのに反し，高龄者群では 4 病日にわたり頻呼吸 が持続し，減少傾向は見られなかった。な和，肺合併症 陽性群と陰性群との対比では，呼吸数はその時の身体状 況により容易に変動し，手術の影響から十分に脱却でき ない 4 病日以内では, 日内変動も激しく, 陽性群と陰性

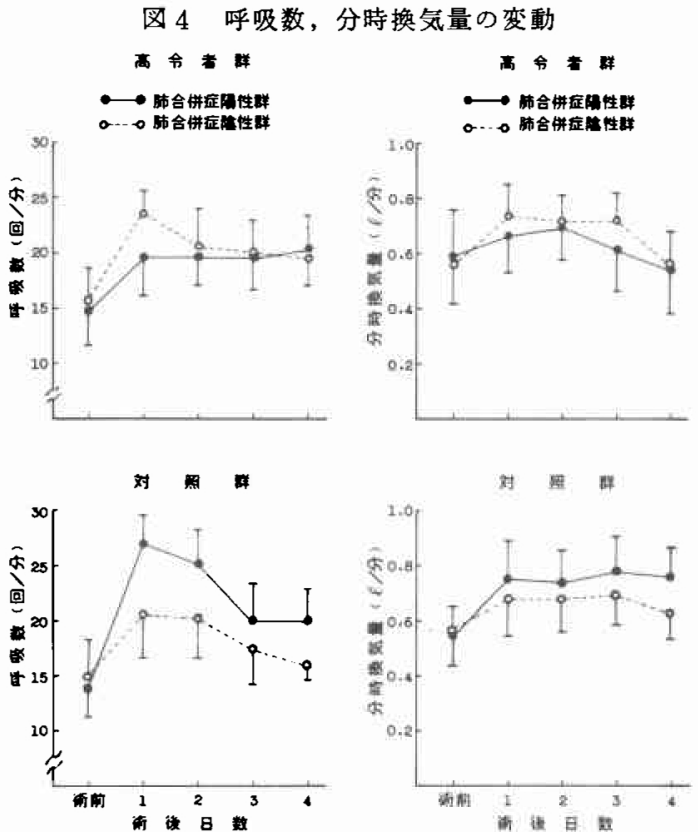

図 5 肺活量回復率

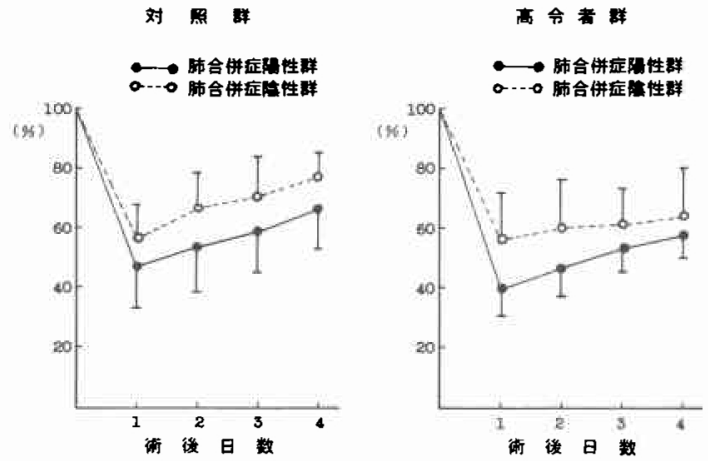

群との間には一定の傾向は見られなかった。

分時換気量の変動（図 4): 分時換気量の 変動では, 対照群の肺合併症陽性群で過換気が遷延した。

肺活量回復率（図 5)：図 5 は術前値を100\%とした術 後の肺活量値の割合を示したものであるが，高龄者群， 対照群ともに第 1 病日では $50 \%$ 近くまで低下し，以後漸 次回復したが，高齢者群の方が回復率が悪かった．高㱓 者群における肺合併症陽性群と陰性群との比較では, 陽 性群で術後肺活量の回復率が悪かった。

呼吸抵抗の変動（図6）：呼吸抵抗は Ossilation 法を 用い，座位にて測定した. 対照群では，肺合併症陽性群 
図 6 呼吸抵抗の変動
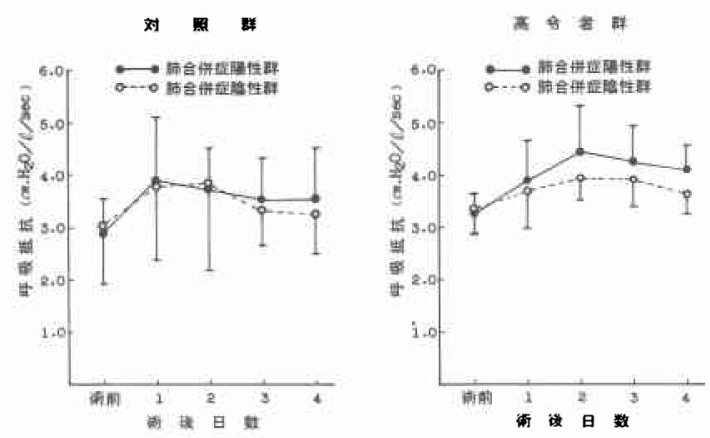

と陰性群との間には術後の 経過に差がなく, 最高値も $4 \mathrm{~cm} \cdot \mathrm{H}_{2} \mathrm{O} / l / \mathrm{sec}$ 以内にとどまった。高龄者群では，呼 吸抵抗は術前, 術後ともに対照群より高値を示し, 肺合 併症陽性群では, 術後 4 病日にわたり,より一層の高值 を示し，4病日に至るも，低下傾向は見られなかった。

末梢動脈血液 ガス値の 変動 (図 7) : 術前値は空気呼 吸下の値で, 術後 1,2 病日では, 酸素吸入例も含まれ
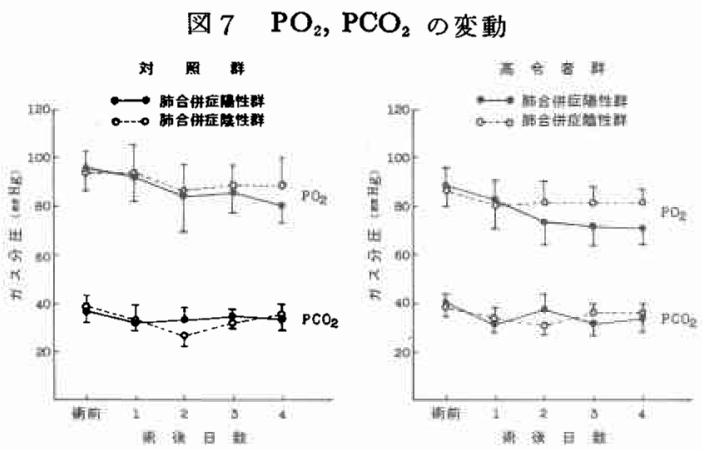

図 8 鎮痡剂と肺活量（第一病日）

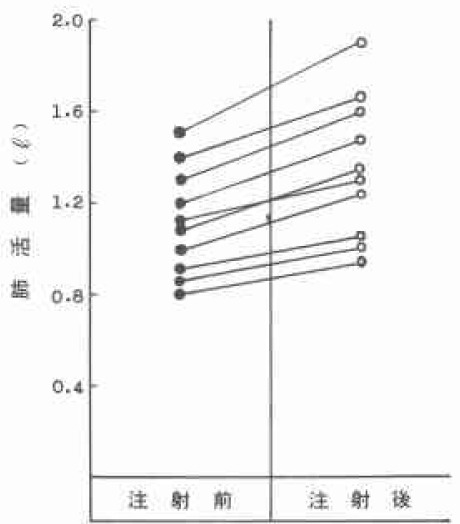

ている. $\mathrm{Po}_{2}$ は高㱓者肺合併症陽性群では, 術後日々低 下傾向を示し，4病日に至るも，回復傾向が見られず， 低酸素血症が要延した. $\mathrm{Pco}_{2}$ は対照群，高㱓者群とも に，術後には軽度低下したが，両群の間には差異は見ら れなかった。

鎮痛剂投与と 肺活量（図8）：術後の疼痛は換気障害 の大きな要因と思われる，そこで，第 1 病日にペンタゾ シン15mg を笳注し，注射前後での肺活量の変化を見 た. 注射後には, 全例肺活量の增加が 見られ，最大 27 $\%$, 平均 $20 \%$ の増加率であったことより，術後の適度の 鎮痛風投与は换気の改善に有効であった。

\section{考察}

患者管理の進歩した現在でも，高㱓者の術後肺合併症 は高頻度に見られ，今るって重要な合併症の1つであ

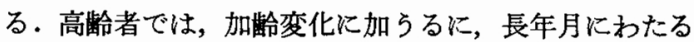
種々の肺病変の蓄積があり, 肺気腫, 慢性気管支炎, 気 管支喘息などの慢性閉塞性肺疾患 (chronic obstructive pulmonary disease : COPD) や，肺線維症などの多彩な 病態を有する例が多く, 肺機能およびその予備力の低下 は著しい。

Comroe $^{1)}$ らによると, 加龄による 肺気量の変動は著 明で, 深吸気量や肺活量の減少, 残気量の増大などが見 られ，20歳代男性に比し50歳代男性では，残気率が 2 倍 の40\%に達するとしている．このような肺機能の低下を 伴なっている高齢者に手術侵襲が加われば，より一層の 肺機能の低下が見られ，術後肺合併症例も増すであろう 事は容易に想像される．林ら ${ }^{2}$ は，加龄とともに肺合併 症発生の頻度が高くなることを指摘している．吉村ら は, 大量輸血を伴う長時間手術では，肺合併症の発生は 必至であり，その発生率は60歳以上の高龄者に高く, 胸 部手術では一般手術の約10倍の発生率であったと報告し ている。

一般に，肺合併症は若年者より高齢者に，下腹部手術 より上腹部手術に，腹部手術より胸部手術に，待期手術 より緊急手術に発生率が高くなっている゙).

1. 術前肺機能之肺合併症

高齢者では，COPD や肺線維症なと゚の併存例が多く, これらにおいては, spirogram 上各パラメーターが低值 を示すのは当然といえる。しかし，高齢者でも壮年者と 変らぬ良好な肺機能を有する者もあり，60歳以上では， 肺機能の幅が非常に広く, 正常値の設定ももずかしいも のがある．また，それに伴って，これら高齢者の術後経 過も多種多様であり，術後管理上困難を感ずるところで 
ある。

spirogram の各パラメーターから, 術後の肺合併症発 生を予測せんとする試みは多数みられるが，その相関を 得るのは仲々困難である．吉村ら"は，術前肺機能と術 後肺合併症発生とは必ずしも相関しないといっている。 著者らの例でも，術前の比肺活量拉よび 1 秒率の値と術 後肺合併症発生との間には相関は見られなかった。

一方, 各パラメーターの組み合わせといら観点から, 田中ら ${ }^{5)}$ は，その組み合わせの利点を述べているが，全 体として見れば，従来の spirogramなどによる術前の静 的状態での呼吸機能検查値から, 術後といら動的状態で の肺合併症発生を予測せんとすることには限界があり， 術前の心肺機能障害の併存は予後悪化の一因子ではある が, 術後の経過は様々であり, 手術適応は心肺機能のみ でなく，多因子により決定さるべぎ ${ }^{6)}$ と考党が一般的 である。

2. $\dot{V}-V$ 曲線

最近, COPD の病態生理が解明されるにつれて, 肺 の silent zone に和计る病変が, 高龄者の呼吸障害の原 因として注目され ${ }^{7)}$ ，従来の spirometer の測定限界にあ った silent zone の変化を $\dot{\mathrm{V}}-\mathrm{V}$ 曲線, closing volume ${ }^{8)}$, 血液ガスの分析などで幅広く把握できるようになった。 逆にいえば, 紐気管支レベルの障害を, 術前に適確に把 握することが，高龄者の術後の呼吸障害を考える上でさ わめて大切といえる。山林ら”は, small airway に淤 る病変の把握の重要性を強調 $\mathrm{V}, \dot{\mathrm{V}}-\mathrm{V}$ 曲線測定の意義 について述べている。

ところで, この $\dot{V}-\mathrm{V}$ 曲線に関しては, Hyatt $ら^{10)} か ゙$ 詳細に検討しているが, 曲線の解析に当って, その定量 化のためのパラメーターの選択には未だ一定のものが出 ていないように思われる. 山林ら ${ }^{99}$ は, $\dot{V}_{50}, \dot{V}_{25}, \dot{V}_{50} / \dot{V}_{25}$ の比較で, $\dot{V}_{50}, \dot{V}_{25}$ などの単独の值の方が $\dot{\mathrm{V}}_{50} / \dot{\mathrm{V}}_{25}$ よ り有用であると述べている。長谷川ら ${ }^{11}$ は, 定量化の 方法として， $\dot{V} / \mathrm{VC} と$ Cherniac \& Raber らによる $\dot{V} \max , \dot{V}_{75}$ などに対する予測式を用い，\% $\%$ を算出し て検討し，卞を絶対值で比較するのは，VC の影響を無 視しているため不合理であり，\%ヴでは予測式を出す に至った対象が問題であるとしている.

つぎに，術後肺合併症検索に対する応用としては， Yoshida $ら^{12)}$ が 各種手術施行後の肺合併症の検討で, $\mathrm{PF}, \dot{\mathrm{V}}_{50}, \dot{\mathrm{V}}_{25}, \dot{\mathrm{V}}_{50} / \dot{\mathrm{V}}_{25}$ などの值では肺合併症陽珄群と 陰性群との間には有意差は無かったとしている。著者ら の検索では, 肺合併症陽性群と陰性群との対比で, 陽性
群では VC を加味した4 $\left(\dot{\mathrm{V}}_{50}-\dot{\mathrm{V}}_{25}\right) / \mathrm{VC}$ が 有意に 低下 し, 低肺気量域における時定数の逆数, 寸なわら, 曲線 の勾配の小さなものには, 術後肺合併症発生が高頻度に 見られ，COPD も含めた何らかの末梢気道の閉塞を有 する例に, 肺合併症が多く見られた事より， small airway obstuction の把握には4 $\left(\dot{\mathrm{V}}_{50}-\dot{\mathrm{V}}_{25}\right) / \mathrm{VC}$ は有用な指 標であると考える.さらに，閉塞性障害の程度の判定に は, $\dot{V}_{50}, \dot{V}_{25}$ などの絶対值で評価するのが妥当と思われ る.

\section{3. 術後肺機能の変動}

高龄者では換気能の低下とガス交換障害が見られ，若 年者と比較すると，一般に低肺機能の状態にあるとい兄 るが，これらが術後さらにどの程度障害されるかという 点は, 術後の呼吸管理上大切なことであり, 以下，次の 2 点について考察したい。

まず，術後換気能では，開腹術後には麻䣲，疼痛，腹 部膨満等の影響により換気抑制が見られるが，これにつ

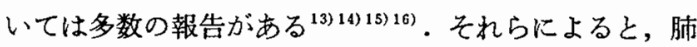
活量, 最大換気量および各種時間肺活量の諸値は, 1 病 日に極度に低下し，以後徐々汇回復するが，術前值にま で回復するのには約 1 週間を要する，さらに，手術部位 の違いや, 同一臓器でも切開創の部位の違いでも, 術後 の肺機能に差が見られるが，胸部，上腹部，下腹部，四 肢々の他の部の手術の順に, 寸なわち, 呼吸運動に関与 する部位への侵襲が多い程, 術後の換気能が 障害され る. 著者らの検索でる, 高龄者の術後では 1 回換気量お よび肺活量の減少，持続する頻呼吸が見られ，肺虚脱を 起こし易い状況にある.ところで, 術後の換気障害の最 大要因の 1 つに疼痛が挙げられるが，適度の鎮痛剤投与 は換気の改善に有効であり, 状況に応じきめ細かく投与 すべきであろう，呼吸抵抗に関しては，高龄者では咳反 射や気道内絨毛運動の低下があり，疢の喀出不良の状態 にあるが，術後の呼吸抵抗は術前に比し約 $20 \%$ 上昇し， $2 ， 3$ 病日に最高になったことからる，術後の呼吸抵抗 增大の主な 要因は気道内分泌物貯留と思われる. 渡辺 $5^{17)}$ も, 気道内分泌物は術後 2 日目より粘稠度を增すと いっている.一般に， 2,3 病日には気道の乾燥化，分 泌物増量の時期に当り,これが原因で疢の喀出障害が起 こり，2，3病日に呼吸抵抗が最大值を示すものと思わ れる.このように, 高龄者の 術後の 換気能障害は顕著 で，肺合併症を起こし易い状況にあり，術前より予防的 に対処するのが最善であろら.

つぎに，術後の hypoxemia について見ると，高龄者 
の酸，塩基平衡では $\mathrm{PH}, \mathrm{PcO}_{2}$ は若年者と余り差はな ( ${ }^{18)}, \mathrm{Po}_{2}$ は加齢とともに低下している ${ }^{199}$.

各種手術後の血液ガスの变動については多数の報告が あるが，一般に， $\mathrm{Pco}_{2}$ は余り変動が見られず，呼吸不 全の状態を除けばをしろ低下傾向を示す， $\mathrm{Po}_{2}$ は正常経 過例に打いては， 2 病日頃に最低値を示し，以後徐々に 回復するが，術前値にまで回復するのには 1 週間または それ以上の日時を要する20).この傾向は高齢者や肺合併 症発生例でより顕著となる。

術後の hypoxemia については色々の分類があるが， まず，換気障害について考察してみたい，開腹術後には かなりの換気障害が見られるが, 実際にはわれわれの検 索結果も示すごとく, 術後には過換気, 頻呼吸の状態に あって， $\mathrm{Pco}_{2}$ は低下傾向にあることより，低換気の影 響は少ないるのと思われる. しかし, 高齡者では残気量 の増大を伴っている上，術後には頻呼吸がつづくことよ り，過換気が必ずしも十分なる肺胞換気を意味している とはいえず，肺胞低換気の状態にある場合もあり，若年 者とは少し意味合いが異なっている。

つぎに拡散障害について見ると, 高龄者で払散障害が 起こり易いのは肺水腫の場合である.術後の不適切な輸 液によっては容易に肺水腫類似状態を惹起する，さら に, 高㱓者消化器疾患患者の場合, 低蛋白血症に基づく 琹質浸透圧の低下による肺水腫もまた重要である。しか し，この拡散障害は術後の hypoxemia の主要因ではな いと考元られる。

shunt は, 換気障害, 拡散障害等の場合の hypoxemia と異なり，純酸素を吸入させても余り $\mathrm{Po}_{2}$ を上げ得な い唯一の hypoxemia の型である゙1.大田ら ${ }^{21}$ は, shunt を shunt 様效果を生を換気血流不均衡と true shunt に分けて，それぞれの立場について論じているが，この 両者は実際の臨床上では，互に重複する面が多く，撖密 に区分けする必要はない上うに思われる，実際には，術 後の疼痛, 腹部膨満などによる機能的残気量の減少が, 平静換気時の airway closure を助長し, 無気肺, 換気 一血流不均衡を招来し，これが術後 hypoxemia の主要 因となり，胸部拉よび上腹部手術例では，その傾向が他 の部の手術に比しより顕著となっているる ${ }^{22) 2324)}$. さら に, 注目すべきことは, 加龄と hypoxemia との関係で ある. Drumond ${ }^{25)}$ は, $\mathrm{PaO}_{2}$ の減少拉よび肺胞気一動脈 血酸素較差の増大は加齢とともに高度となり, 術後には その傾向が助長されると述へ，加龄が hypoxemia の最 大要因の1つであると強調している.
以上のことからも, 可逆的または不可逆的な気道閉塞 に起因する micro or massive atelectasis が術後 hypoxemia の主要因であり，とくに，術前よりCOPDを有 する高齢者患者では，術後無気肺と招来し易いといえ る.それゆえ，高龄者の呼吸管理に当っては，術前に可 及的全身状態の改善を図り, 術後には, 術直後よりのき め細かい呼吸管理が大切である。

\section{結 語}

70 歳以上の高㱓者の開腹手術前後の肺機能を spirogram, $\dot{V}-V$ 曲線, 呼吸抵抗, 動脈血ガス分析の点から 検討し，以下の成績を得た。

1. 高秢者では, 無気肺, 肺炎, 胸水貯留などの術後 肺合併症は $48 \%$ 之高頻度に発生した。

2. 術前の spirogram では，高龄者には1秒率の低 下例が 多いが，肺合併症発生との相関は得られなかっ た。

3. $\dot{\mathrm{V}}-\mathrm{V}$ 曲線は COPD や肺線維症などの老人性变化 の検出に有用であり， $4\left(\dot{V}_{50}-\dot{V}_{25}\right) / V C$ が，肺合併症発 生と有意の相関を示した $(\mathrm{p}<0.001)$.

4. 術後早期の換気能障害は著しく, 術前值に回復す るのに䄪 1 週間を要し, 高龄者肺合併症発生例では, こ の傾向はより顕著であった。

5. 術後の hypoxemia は無気肺们起因する shunt が 主要因であり，術後 1 週間またはそれ以上も持続した。

6. 術後の疼痛は換気障害の主要因であり, 適度の鎮 痛㓮投与は換気の改善に非常に有効であった.

\section{文献}

1) Comrore, J.H., et al.: The Lung. 2nd. ed. Year Book, Chicago, 1962.

2) 林 四郎汪か：老人と術後肺合併症, とくに術 前Spirogram と術後動脈血酸素飽和度の関連性 を中心にして。老年病， 7:769-778，1963.

3) 吉村敬三汪分: 呼吸器系障害. 手術 XXIX : 403-408, 1975.

4) 四方淳一住か：呼吸器合併症. 外科款療, 19： $284-290,1977$.

5）田中大平ほか：老人外科之肺機能. 外科, 34 : 1339-1346, 1972 .

6) 吉竹 毅 : 心肺機能障害. 外科, 38 ：1216$1223,1976$.

7) 滝島 任活か：肺機能検査による診断の限界と 評価. 肺之心 XVIII : 212-216, 1971 .

8) 大久保隆男 義. 肺と心, XXII : 38-46, 1975.

9) 山林 一 : Flow-Volume 曲線測定と意義. 肺と 心, XXII : 47-52, 1975. 
10) Hyatt, R.E., et al.: Relationship between maximum expilatory flow and degree of lung inflation. J. Appl. Physiol., 13: 331-336, 1958.

11）長谷川克ほか: 肺癌症例における Flow-Volume 曲線の検討。癌の臨床, $23: 537-540,1977$.

12) Yoshida, T., et al.: Evaluation of the risk of postoperative pulmonary complications. Jap. J. Surg., 7: 131-138, 1977.

13）砂田輝武ほか：急性呼吸不全の臨床，外科，33： 1212-1216, 1971.

14) Hansen, G., et al.: Pulmonary complications, ventilation and blood gases after upper abdominal surgery. Acta Anaesth. Scand., 21: $211-215,1977$.

15) Black, J., et al.: The effect of the surgical approach on respiratory function after esophageal resection. Br. J. Surg., 64: $624-627$, 1977.

16) Lindell, P., et al.: Ventilation efficiency after different incisions for cholecystectomy. Acta Chir. Scand., 142: 561—565, 1976.

17）渡辺 寛ほか：高令者開腹術後の肺合併症予防 策. 日本消化器外科学会第 9 回総会抄録集上
り $98,1976$.

18）林四郎：老人外科と酸 - 塩基平衡. 外科, 34: $1355-1364,1972$.

19) Nunn, F.F., et al.: Influence of age and other factors on hypoxemia in the postoperative period. Lancet, 2: 466-468, 1965.

20) Parfrey, P.S., et al.: Pulmonary function in the early postoperative period. Br. J. Surg., 64: $384-389,1977$.

21）大田満夫汪か: 術後低酸素血症. 日胸外会誌, 19 : 549-558, 1971.

22) Palmer, K.N.V., et al.: Effect of partial gastrectomy on pulmonary physiology. $\mathrm{Br}$. Med. J., 8: 347-349, 1964.

23) Knudsen, J.: Duration of hypoxaemia after uncomplicated upper abdominal and thoracoabdominal operations. Anaesthesia, 25: 372377, 1970.

24) Hewlett, A.M., et al.: Postoperative pulmonary function. Br. J. Anaesth., 47: 103-107, 1975.

25) Drummond, G.B.: Postoperative hypoxaemia and oxygen therapy. Br. J. Anaesth., $47: 491-$ 499, 1975. 